\title{
Science literacy, critical thinking skill, and motivation: A correlational study
}

\author{
Rosita Primasari a,1, Mieke Miarsyah a,2,", R. Rusdi a,3 \\ a Universitas Negeri Jakarta, Jl. Rawamangun Muka, RT.11/RW.14, Kota Jakarta Timur, Daerah Khusus Ibukota Jakarta 13220, \\ Indonesia \\ 1 primasari.rosita@gmail.com, ${ }^{2}$ mmiarsyah@unj.ac.id*; ${ }^{3}$ rusdi@unj.ac.id \\ ${ }^{*}$ Corresponding author
}

\begin{tabular}{|c|c|}
\hline ARTICLE INFO & ABSTRACT \\
\hline $\begin{array}{l}\text { Article history } \\
\text { Received January 27, } 2020 \\
\text { Revised June } 02,2020 \\
\text { Accepted June 17, } 2020 \\
\text { Published July 21, } 2020 \\
\text { Keywords } \\
\text { Critical thinking skills } \\
\text { Motivation } \\
\text { Science literacy }\end{array}$ & 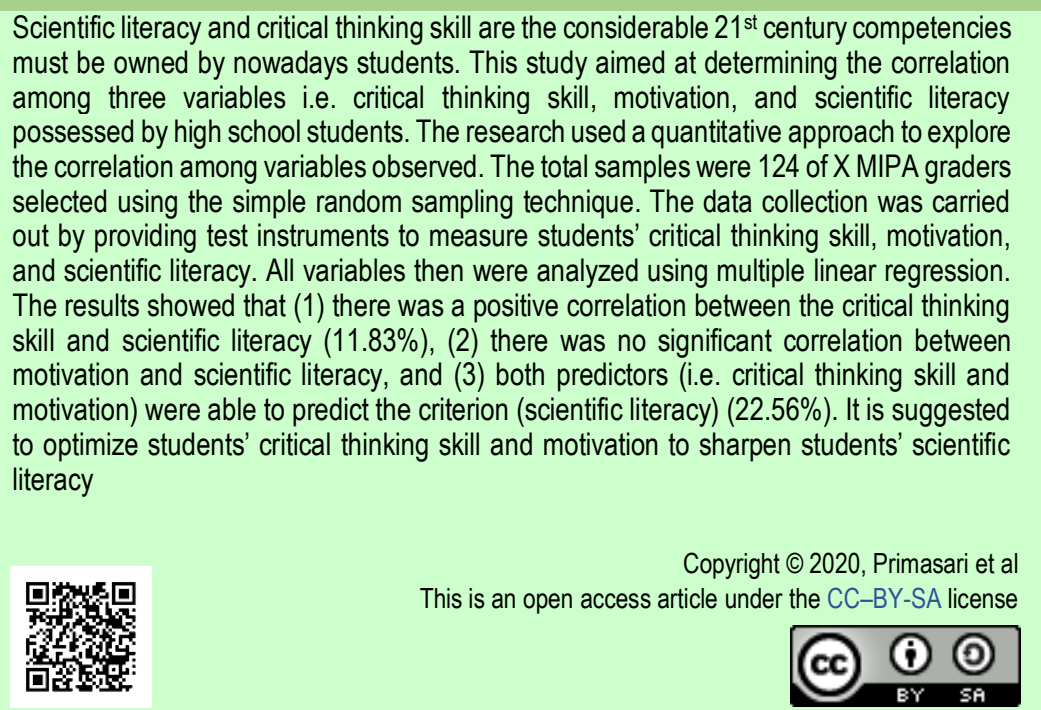 \\
\hline $\begin{array}{r}\text { How to cite: Primasar } \\
\text { study. JF }\end{array}$ & $\begin{array}{l}\text {, \& Rusdi, R.. (2020). Science literacy, critical thinking skill, and motivation: A correlationa } \\
\text { ikan Biologi Indonesia), 6(2), 273-282. doi: https://doi.org/10.22219/jpbi.v6i2.11124 }\end{array}$ \\
\hline
\end{tabular}

\section{INTRODUCTION}

Scientific literacy of Indonesian students in 2018 is in position 70 out of 78 participating countries with a score of 396 below the average PISA standard (OECD, 2019). That number is far from the score where the average gained by all PISA participating countries with an average score of 489 for scientific literacy. This result designates the low scientific literacy skills of Indonesian students. Several crucial factors related to the acquisition of scientific literacy are critical thinking skill and learning motivation (Suisiati et al., 2018; Wahyuni et al., 2018). A low score of students' scientific literacy skill indicates that the students' critical thinking ability is low as well (Rahayuni, 2016). Through scientific literacy, it is expected that the students are able to enhance their thinking skill in analyzing a reading material to solve problems.

Scientific literacy is defined as a skill in using knowledge about science to solve problems and make scientific decisions along with the responsibility (Holbrook \& Rannikmae, 2009). The scientific literacy is a human activity carried out by means of understanding as well as making decisions about nature and changes to the nature involving the possessed knowledge and technology (OECD, 2010). Scientific literacy is a skill to comprehend, 
communicate, and implement scientific knowledge to solve the problems arisen (Toharudin, Hendrawati, \& Rustaman, 2011).

Critical thinking is an intellectual process in analyzing, integrating, and evaluating any information acquired as guidance to act and make decisions (Mulnix, 2012). Critical thinking is interpreted as a skill in considering, processing information, analyzing, and making justifiable conclusions (Jariyah, 2017). Critical thinking skill is an essential skill possessed by someone who focuses on problem-solving (Ghazivakili et al., 2014; Karakoç M, 2016; Radulović \& Stančić, 2017). The students are compulsory to develop their analyzing skill, processing the information received so that the students are able to make decisions to solve a problem (Häkkinen et al., 2017).

The main objective of formal education is about learning how to think (Bernard et al., 2008). In this case, the students can be avowed to think critically if the students are able to remember, interpret, analyze, construct their knowledge, and assess or decide a conclusion to solve problems. Those problems can be solved if the students have a good scientific literacy skill (Rahayu, 2014). The students who have good literacy indicate that the students are able to use their knowledge to think critically in solving a problem well (Ulger, 2018).

The scientific literacy skill possessed by the students is closely related to the critical thinking skill (Singh, Kaur, \& Brar, 2017). An exertion to evolve a literacy spirit in the students' self is not easy; it is required motivation in the learning processes. Motivation is a process carried out by someone to attain a goal by considering the intensity, aims, and perseverance (Stephen P. Robbins \& Judge, 2012). Motivation is defined as a strength or encouragement for someone who tries to achieve the goals that he/she wants (Everaert, P., et al, 2017; Husamah \& Pantiwati, 2014). This can be interpreted that the more students have critical thinking skill and high motivation will have good scientific literacy values and vice versa (Susiani, Salimi, \& Hidayah, 2018). The stronger the motivation to learn, the higher the results of critical thinking skill achieved by the students (Anisa, 2017).

Scientific literacy is important for the students to be able to produce critical and solution thinking from each information received. This study is necessary to be conducted since it is suspected that critical thinking skill and motivation are simultaneously related to the students' scientific literacy skill. According to Rahayuni (2016), critical thinking skill is regarded as one of the factors that may affect scientific literacy. An individual who has critical reading skill has positive effect to the scientific literacy skill; thru this skill, the attitudes towards scientific literacy become meaningful (Karademir \& Ulucinar, 2016). Based on (Wahyuni et al., 2018), the higher the achievement motivation of students, the higher their scientific literacy skills. However, previous study has never been done on the critical thinking skill and the students' motivation to improve the scientific literacy skill. This study becomes very important to be studied more deeply to discover the correlation between the critical thinking skill and motivation to the scientific literacy of High School students (SMA). The results of this study can be used as a basic reference or consideration for the further studies to analyze the matters that can affect the scientific literacy.

\section{METHOD}

The descriptive method was used as the method of study thru a quantitative approach using correlational technique. This study consisted of three variables that would be investigated, namely critical thinking skill $\left(X_{1}\right)$, motivation $\left(\mathrm{X}_{2}\right)$, and scientific literacy skill $(\mathrm{Y})$. The subjects of the study were the students of SMAN 5 Depok in the academic year of 2019/2020, in which the number of samples were 12 students of $10^{\text {th }}$ grade of Mathematics and Natural Science (MIPA); moreover, the samples were selected using Simple Random Sampling technique. The data of this study were taken by distributing several instruments to the respondents including of test instrument of critical thinking skill, motivation test, and scientific literacy test. The test instrument of critical thinking was in the form of essay items measured using assessment rubric, the motivation test was in the form of questionnaire, and the scientific literacy test was in the form of a description formulated based on the PISA indicators. This study used data analysis techniques involved of prerequisite test of data analysis and hypothesis test. The prerequisite test indicated the data that normally distributed and homogeneous variance. The hypothesis test was done through multiple regression and correlation tests.

\section{RESULTS AND DISCUSSION}

Based on the results of study, it was known that the three variables (critical thinking skill, motivation, and scientific literacy) had a mean score for each of them, namely $44.52,76,17$, and 61,52 . The highest score of critical thinking ability was 64 , for motivation was 97 and the scientific literacy was 88 . The lowest score of critical thinking skill was 21 , motivation was 67 , while the scientific literacy was 34 . The score of critical thinking skill had a score difference of 43 , motivation value had a difference of 30 , and the score of scientific literacy had a score difference of 54 (Table 1). 
Table 1. Research descriptive statistics

\begin{tabular}{lccc}
\hline & Critical thinking & Motivation & Scientific literacy \\
\hline Samples & 124 & 124 & 124 \\
Maximum Score & 64 & 97 & 88 \\
Minimum Score & 21 & 67 & 34 \\
Standard Deviation & 9,028 & 5,382 & 11,685 \\
Mean & 44,52 & 76,17 & 61,52 \\
\hline
\end{tabular}

According to the data of study, the students who had a score of critical thinking skill above the average were 65 respondents $(52 \%)$ and 59 respondents (48\%) got a score below the average. This result was obtained after conducting an assessment on several indicators of critical thinking i.e. the students' skills in interpreting, analyzing, evaluating, concluding, explaining, and self-regulating. The students who had the motivation score above the average were 65 respondents $(52 \%)$ and 59 respondents $(48 \%)$ were still below the average score. This result was gained after conducting a motivation test to the students including three dimensions of intensity, aims, and perseverance. The scientific literacy test results indicated that the students who had a score above the average were 67 respondents (54\%) and there were 57 respondents $(46 \%)$ who still got a score below the average score.

The results of the normality test used Kolmogorov-Smirnov test indicated that the three groups of critical thinking, motivation, and scientific literacy data were normally distributed. The homogeneity test results indicated that the data variance was homogenous.

In the hypothesis test of the correlation between critical thinking skill (X1) and scientific literacy (Y), the regression model test used was a simple linear regression, in which it could be seen in the Table 2.

Table 2. Regression model test between critical thinking skill and scientific literacy

\begin{tabular}{ccccccc}
\hline \multirow{2}{*}{ Model } & \multicolumn{2}{c}{ Unstandardized Coefficients } & Standardized Coefficients & \multirow{2}{*}{ T } & \multirow{2}{*}{ Sig. } \\
\cline { 2 - 4 } & B & Std. Error & Beta & & 8.339 & .000 \\
1 1 (Constant) & 41.694 & 5.000 & & .344 & 4.046 & .000 \\
Critical_Thinking & .445 & .110 & &
\end{tabular}

Dependent Variable: Scientific_Literacy

Table 3 exposed the ANOVA results to discover the variable significantly whether it had a correlation to the criteria or not. According to the Table 3 , the statistical value of $F$ was 16,379 with the score of $p<a(0.05)$. It could be inferred that the critical thinking skill had a correlation with the scientific literacy.

Table 3. Significance test of regression model

\begin{tabular}{lllllcl}
\hline & Model & Sum of squares & Df & Mean square & Sum of squares & Sig. \\
\hline \multirow{4}{*}{1} & Regression & 1987.710 & 1 & 1987.710 & 16.379 & $.000 \mathrm{~b}$ \\
& Residual & 14805.217 & 122 & 121.354 & & \\
\cline { 3 - 4 } & Total & 16792.927 & 123 & & & \\
\hline
\end{tabular}

Based on the significance test and linearity test of regression model $\hat{Y}=41,694+0,445 \mathrm{X} 1$, it could be concluded that the equation was significant and linear (Figure 1).

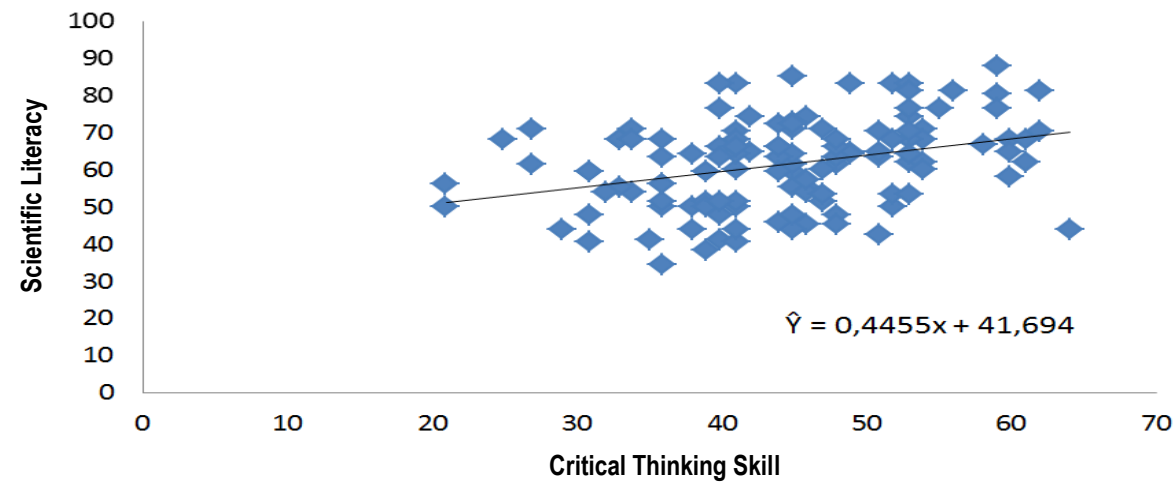

Figure 1. Simple linear regression model between critical thinking skill $(X 1)$ and scientific literacy $(Y)$ 
Table 4. Correlation test between critical thinking skill (X1) and scientific literacy $(Y)$

\begin{tabular}{llll}
\hline & & Critical thinking & Scientific literacy \\
\hline \multirow{3}{*}{ Critical thinking } & Pearson Correlation & 1 & $.344^{* *}$ \\
& Sig. (2-tailed) & & .000 \\
& $N$ & 124 & 124 \\
\multirow{5}{*}{ Scientific literacy } & Pearson Correlation & $.344^{* *}$ & 1 \\
& Sig. (2-tailed) & .000 & 124 \\
& $\mathrm{~N}$ & 124 & 124 \\
\hline
\end{tabular}

Based on the Table 4, it could be explicated that the correlation coefficient (rx1y) between critical thinking skill $(X 1)$ and scientific literacy $(Y)$ was 0,344 . The score of rx1y $=0,344$ indicated a positive correlation, and the obtained significance values was $<a(0.05)$. From this data, there was significant correlation between critical thinking skill (X1) and scientific literacy $(Y)$.

Based on the data, coefficient of determination between critical thinking skill $(X 1)$ and scientific literacy $(Y)$ was 0,118 . It meant that the critical thinking skill had a contribution of $11.83 \%$ in the scientific literacy. This was in line with previous study carried out by Rahayuni (2016), the scientific literacy is influenced by critical thinking skill with strong criteria, in which the cognitive factor owned by the students will be influenced by the scientific literacy skill.

Increased critical thinking skill will improve the scientific literacy skill. The results of study conducted by Glaze (2018) stated that the increased scientific literacy skill is not only influenced by the ability to memorize and apply science concepts in the classroom, but it is influenced by the depth of thinking, understanding the process of scientific knowledge so that the students can discover their own concepts by exploring their knowledge, this can happen if someone is able to think critically about the scientific knowledge they face.

The weakness of relationship between critical thinking skill and scientific literacy was assumed to be due to the low reading interest of students. Low reading interest was assumed to be due to the absence of reading activities that could lead to a habit (Johari, Tom, Morni, \& Sahari, 2013). Reading habits could form critical and constructive thinking patterns so that the students had the ability to read a comprehension. The creation of reading habits can support the students' literacy skill (Nurul et al., 2018). A literacy needed reading and understanding skills about an article well. Article on scientific literacy test and critical thinking which was quite long caused the students to become lazy and unable to fully concentrate on answering the questions given (Cargas, Williams, \& Rosenberg, 2017). Similar to what had been disclosed by Purwani et al., (2018) that the scientific literacy of $10^{\text {th }}$ grade students of High School in Bandung Barat on the biodiversity issues had low score, this is because most of students are getting lazy to read the science literacy test articles. According to Saptasari et al., (2019), low reading skill contributes to lower levels of information literacy skill in education.

Competency in scientific literacy covered up the critical thinking processes that needed to involve the ability to analyze, interpret information, draw conclusions, and look for the solution of problem-solving, in which those are used to be implemented in life (Suwono, Mahmudah, \& Maulidiah, 2017). This was in line to Zascavage (2010) that critical thinking is not only about the ability to interpret, evaluate, conclude, and assess, but also able to implement those skills in education developments. The critical thinking skill can be improved by means of a presentation activity so that the students can analyze and synthesize the learning (Lukitasari, Hasan, \& Murtafiah, 2019).

The students needed to train their critical thinking skill in solving the problems by getting used to literacy. This was reinforced by Cahyana et al., (2017) that the students' scientific literacy can improve since there is a critical thinking, where in the critical thinking processes involved an ability to interpret information and explore the solutions about the problems face up. The Correlation between Motivation (X2) and Scientific Literacy (Y) the regression model test used was a simple linear regression. Referred to the Table 5.

Table 5. Regression model test between motivation $(X 2)$ and scientific literacy $(Y)$

\begin{tabular}{|c|c|c|c|c|c|c|}
\hline \multirow[t]{2}{*}{ Model } & & \multicolumn{2}{|c|}{ Unstandardized Coefficients } & \multirow{2}{*}{$\begin{array}{c}\text { Standardized Coefficients } \\
\text { Beta } \\
\end{array}$} & \multirow[t]{2}{*}{$\mathrm{T}$} & \multirow[t]{2}{*}{ Sig. } \\
\hline & & B & Std. Error & & & \\
\hline \multirow{2}{*}{1} & (Constant) & 109.683 & 14.357 & & 7.640 & .000 \\
\hline & Motivation & -.632 & .188 & -.291 & -3.363 & .001 \\
\hline
\end{tabular}

a. Dependent Variable: Scientific Literacy

Table 6 disclosed the ANOVA result to discover the variables which significantly has a correlation with the criteria or not. Based on the Table 6 , the statistical value of $F$ was 11,308 , in which the value of $p$ was $>a(0.05)$. Thus, it could be concluded that motivation had no correlation with the scientific literacy. 
Table 6. Significance test of regression model

\begin{tabular}{lllllll}
\hline & Model & Sum of squares & Df & Mean square & F & Sig. \\
\hline \multirow{4}{*}{1} & Regression & 1424.478 & 1 & 1424.478 & 11.308 & $.000 \mathrm{~b}$ \\
& Residual & 15368.450 & 122 & 125.971 & & \\
\hline
\end{tabular}

From the significance test and linearity test of regression model $\hat{Y}=109,683-0,632 X 2$, it could be concluded that the equation was significant and linear.

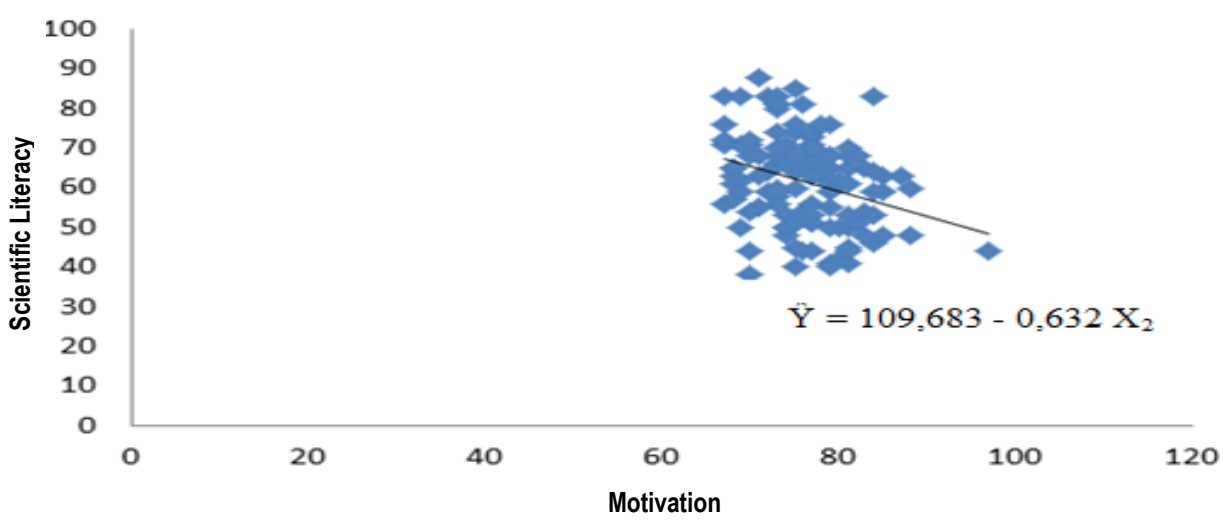

Figure 2. Simple linear regression model between motivation $(X 2)$ and scientific literacy $(Y)$

Furthermore, the value of $\hat{Y}=109,683-0.632 X 2$ was obtained based on the provisions afterwards a simple linear regression test as shown in the Figure 2. According to this equation, it could be interpreted if there was an improvement of 1 score in motivation (X2) so that it would be followed by a decrease in scientific literacy of 0,632 $(Y)$, in which it was 0,632 on the constant of 109,683 thru a regression model of $\hat{Y}$.

Table 7. Correlation test between motivation $(\mathrm{X} 2)$ and scientific literacy $(\mathrm{Y})$

\begin{tabular}{llll}
\hline & & Motivation & Scientific literacy \\
\hline \multirow{3}{*}{ Motivation } & Pearson Correlation & 1 & $-.291^{* *}$ \\
& Sig. (2-tailed) & & .001 \\
Scientific Literacy & $\mathrm{N}$ & 124 & 124 \\
& Pearson Correlation & $-.291^{* *}$ & 1 \\
& Sig. (2-tailed) & .001 & \\
& $\mathrm{~N}$ & 124 & 124 \\
\hline
\end{tabular}

The correlation coefficient (rx2y) among motivation (X2) and scientific literacy $(Y)$ was $-0,291$. The value of $r \times 2 y=-0,291$ indicated that the correlation was positive. Based on this data, there was no significant correlation between motivation (X2) and scientific literation (Y) (Table 7).

Based on the data, the coefficient of determination between critical thinking skill (X1) and scientific literacy (Y) was 0.85 . This meant that the motivation had $8.5 \%$ contribution to the scientific literacy. The correlation was found to be negative, meaning that the increase in motivation would reduce the scientific literacy. The results of this study indicated that there was no correlation between motivation and scientific literacy. This was reinforced by a study conducted by El Islami et al (2015) that the scientific literacy is not related to the level of self-confidence of students. It meant that self-confidence was an internal factor similarly to the motivation that had no effect on the scientific literacy because if only limited to self-confidence and desire without any definite action or activity there would be no result. A motivation was an encouragement in individual that could include self-confidence to reach a goal.

Additionally, the results of this study was not in line to (Handayani, et al, 2015) who asserted that there is a contribution related to the attitude, perception, and motivation of scientific learning to the scientific literacy. According to a study conducted by Lishinski (2016), there is a correlation between biological curiosity and scientific literacy skill, in which it is in a moderate criteria. Motivation had a big contribution to biological learning outcomes (Firmansyah, Komala, \& Rusdi, 2018). The higher the motivation of students, the greater the desire to 
learn and have literacy skills. An increase in achievement motivation is followed by an increase in scientific literacy, the higher the motivation for more achievement from students, the higher the ability of scientific literacy (Wahyuni et al., 2018).

The results of this study were not in line to previous study and it had a negative correlation since there was a difference in the motivation score and the students' scientific literacy. The students who had high motivation but often had low scientific literacy scores, as well as the students who had low motivation but have high scientific literacy scores. It signified that the students' motivation might vary depending on the situation and individual condition. Motivation, in this case, cannot influence the scientific literacy directly due to the motivation that is an encouragement inside to achieve a goal. While in reaching out a good scientific literacy, it is needed not only a motivation but also real action in the form of reading activity that can hone the understanding about the meaning of a literature or reading material and construct their knowledge owned before with new knowledge obtained (Nurul et al., 2018).

The Correlation between Critical thinking Skill (X1) and Motivation (X2) with Scientific Literacy ( $Y$ ) Regression model test used was a multiple linear regression test. Based on the data, it was obtained the significance value of $a<0.05$, in which it could be seen in the Table 8 .

Table 8. Test of $L$ regression model between critical thinking skill (X1), motivation (X2), and scientific literacy $(Y)$

\begin{tabular}{|c|c|c|c|c|c|c|}
\hline & \multirow{2}{*}{ Model } & \multicolumn{2}{|c|}{ Unstandardized coefficients } & \multirow{2}{*}{$\begin{array}{l}\text { Standardized coefficients } \\
\text { Beta }\end{array}$} & \multirow{2}{*}{$\mathrm{T}$} & \multirow{2}{*}{ Sig. } \\
\hline & & B & Std. Error & & & \\
\hline \multirow[b]{2}{*}{1} & (Constant) & 94.234 & 13.663 & & 6.897 & .000 \\
\hline & $\begin{array}{l}\text { Critical Thinking } \\
\text { Motivation }\end{array}$ & $\begin{array}{l}.489 \\
-.715\end{array}$ & $\begin{array}{l}.104 \\
.175\end{array}$ & $\begin{array}{l}.377 \\
-.329\end{array}$ & $\begin{array}{l}4.692 \\
-4.096\end{array}$ & $\begin{array}{l}.000 \\
.000\end{array}$ \\
\hline
\end{tabular}

a. Dependent Variable: Scientific_Literacy

Table 9 implied the ANOVA results to discover the variable that significantly had a correlation with the criteria or not. Departing from the Table 9, the statistical value of $F$ was 17.633 with the value of $p<\alpha(0.05)$. It could be concluded that the critical thinking skill and motivation had a correlation with the scientific literacy.

Table 9. Significance test of regression model

\begin{tabular}{|c|c|c|c|c|c|c|}
\hline & Model & Sum of squares & Df & Mean square & Sum of squares & Sig. \\
\hline \multirow[b]{2}{*}{1} & Regression & 3789.866 & 2 & 1894.933 & 17.633 & $.000 \mathrm{~b}$ \\
\hline & $\begin{array}{l}\text { Residual } \\
\text { Total }\end{array}$ & $\begin{array}{l}13003.062 \\
16792.927\end{array}$ & $\begin{array}{l}121 \\
123\end{array}$ & 107.463 & & \\
\hline
\end{tabular}

Based on the linearity test, it was obtained the significance value of $<a(0.05)$, the meaning was that the model of the correlation between critical thinking skill and motivation with scientific literacy was linear.

Table 10. Multiple correlation test between critical thinking skill (X1), motivation (X2), and scientific literacy $(Y)$

\begin{tabular}{|c|c|c|c|c|c|c|c|c|c|}
\hline \multirow{2}{*}{ Model } & \multirow{2}{*}{$\mathbf{R}$} & \multirow{2}{*}{ R Square } & \multirow{2}{*}{$\begin{array}{l}\text { Adjusted R } \\
\text { Square }\end{array}$} & \multirow{2}{*}{$\begin{array}{l}\text { Std. Error of the } \\
\text { Estimate }\end{array}$} & \multicolumn{5}{|c|}{ Change Statistics } \\
\hline & & & & & R Square Change & F Change & df1 & df2 & Sig. F Change \\
\hline 1 & $475 a$ & .226 & .213 & 10.366 & .226 & 17.633 & 2 & 121 & .000 \\
\hline
\end{tabular}

a. Predictors: (Constant), Motivation, Critical_Thinking

b. Dependent Variable: Scientific_Literacy

Based on the multiple correlation test (Table 10), it was obtained that the multiple correlation coefficient ( $\mathrm{x}$ 1x2y) of critical thinking skill $(\mathrm{X} 1)$ and motivation $(\mathrm{X} 2)$ as well as the scientific literacy $(\mathrm{Y})$ is 0,475 which indicated a positive correlation. Furthermore, also obtained a significance value $<\alpha(0.05)$. Based on this data, there was a significant correlation to critical thinking skill (X1) and motivation (X2) together with the scientific literacy $(Y)$.

Based on the data, the coefficient of determination between critical thinking skill (X1) and motivation (X2) with the scientific literacy $(Y)$ was 0226 . This signified that the skill to think critically and motivation together contributed to the scientific literacy by $22.56 \%$. The results of this study indicated that there was a correlation between critical thinking skill and motivation together with the scientific literacy. This was in line with several study results which postulated that scientific literacy can be positively related to higher order thinking skills and intelligence levels (Yuriza, Adisyahputra, \& Sigit, 2018), reading comprehension skill (Susiati et al., 2018), and scientific process skill (Handayani, Adisyahputra, \& Indrayanti, 2018). 
There was a difference between the study that had been conducted with other relevant studies, namely in experimental study that the correlation between critical thinking skill and scientific literacy was more improved with the Problem-Based Learning (PBM) model compared to the Science and Technology Community (STM) model (Rahayuni, 2016). A positive interaction between the learning model and motivation will influence on the scientific literacy (Bagiarata, et al., 2018). Both experimental studies stated that critical thinking skill and scientific literacy can be improved through learning models applied in schools. This indicates that students' scientific literacy only depends on the learning model used in schools. In addition, there was also path analysis study which stated that there is a direct influence between self-efficacy and motivation on learning outcomes (Firmansyah et al., 2018; Lishinski, Yadav, Good, \& Enbody, 2016). According to those studies, there is direct influence between self-efficacy and motivation; hence, the level of motivation to learn from students was determined by self-efficacy in the students themselves.

Based on these studies, this study discussed how the correlation between critical thinking skill and motivation and scientific literacy of high school students. The test results on the correlation between critical thinking skill and motivation with scientific literacy showed a positive correlation. This indicated that increasing critical thinking skill and motivation would increase the students' scientific literacy skill. The critical thinking was a person's way of being able to decide what to believe and do so that it affected the level of critical thinking. The motivation would assist the students to think better. The students who were motivated would be honed their critical thinking skill so that they got better science literacy scores than those without motivation. The students who had good scientific literacy scores would also have good critical thinking scores (Suwono, Pratiwi, Susanto, \& Susilo, 2017). This study was supported by Hasenbank (2006) who asserted that the students who have good scientific literacy will have a high level of thinking skill, since in the scientific literacy the students are required to implement the knowledge possessed by the students into daily life.

The students would have motivation, learning achievement that covered up the critical thinking skill and good scientific literacy when supported by collaborative learning from the teachers. As formulated in the curriculum of 2013, collaborative learning would teach the students to think critically. This was in line with Bryan et al (2011) that the science teachers have to use social modeling and collaborative activities to foster the students' motivation, achievement, and interest in science careers. Based on the explanation above, the skill to think critically and motivation simultaneously could support the students' scientific literacy skill.

The implication obtained from the results of this study could be used as a reference for further studies by adding dependent variables or analyzing things that could affect the critical thinking skill and scientific literacy. This could also have implications for the teacher policies to innovate learning methods and models that could develop the critical thinking skill, increase the students' motivation and scientific literacy. The information obtained from the results of this study could be used as a reference for the students to improve their scientific literacy skill with the support of critical thinking and motivation in themselves. The role of teachers was needed to develop the critical thinking skill, motivation, and scientific literacy of students in the learning process.

\section{CONCLUSION}

Departing from the results data of study and discussion, it can be concluded that there is a positive correlation between critical thinking and scientific literacy, in which the contribution is $11.83 \%$. There is no correlation between motivation and scientific literacy. There is a positive correlation between critical thinking skill and motivation together with the scientific literacy, in which the contribution is $22.56 \%$. The researchers suggest that further study is needed to be carried out, of which study can analyze more about the factors related to the critical thinking skill, motivation, and scientific literacy. It is necessary to carry out an improvement of learning quality that is able to motivate in the learning, to stimulate the critical thinking skill, and scientific literacy skill for the students thru a model innovation and learning method implemented in the school.

\section{ACKNOWLEDGEMENT}

This section can be written in case there are certain parties need to be acknowledged, such as research sponsors. The acknowledgement must be written in brief and clear. In addition, avoid the hyperbole acknowledgment.

\section{REFERENCES}

Anisa. (2017). Hubungan motivasi belajar dengan keterampilan berpikir kritis siswa pada pembelajaran konsep 
sistem pencernaan menggunakan model pembelajaran experiential learning. Jurnal BioEdUIN, 7(2), 113. Retrieved from https://journal.uinsgd.ac.id/index.php/bioeduin/article/view/3148

Bagiarata I. N., K. I. W. \& S. I. N. (2018). Komparasi literasi sains antara siswa yang dibelajarkan dengan model pembelajaran kooperatif tipe GI (group investigation) dan model pembelajaran inkuiri terbimbing (guided inquiry) ditinjau dari motivasi berprestasi siswa SMP. Jurnal Pendidikan Dan Pembelajaran IPA Indonesia, 8(1), 16-25. Retrieved from https://119.252.161.254/e-journal/index.php/jurnal_ipa/article/vie $w / 2923$

Bernard, R. M., Zhang, D., Abrami, P. C., Sicoly, F., Borokhovski, E., \& Surkes, M. A. (2008). Exploring the structure of the Watson-Glaser Critical Thinking Appraisal: One scale or many subscales? Thinking Skills and Creativity, 3(1), 15-22. doi: https://doi.org/10.1016/j.tsc.2007.11.001

Bryan, R. R., Glynn, S. M., \& Kittleson, J. M. (2011). Motivation, achievement, and advanced placement intent of high school students learning science. Science Education, 95(6), 1049-1065. doi: https://doi.org/10. 1002/sce.20462

Cahyana, U., Kadir, A., \& Gherardini, M. (2017). Relasi kemampuan berpikir kritis dalam kemampuan literasi sains pada siswa kelas IV sekolah dasar. Sekolah Dasar: Kajian Teori dan Praktik Pendidikan, 26(1), 1422. doi: https://doi.org/10.17977/um009v26i12017p014

Cargas, S., Williams, S., \& Rosenberg, M. (2017). An approach to teaching critical thinking across disciplines using performance tasks with a common rubric. Thinking Skills and Creativity, 26, 24-37. doi: https:/l doi.org/10.1016/j.tsc.2017.05.005

El Islami, R. A. Z., Nahadi, N., \& Permanasari, A. (2015). Hubungan literasi sains dan kepercayaan diri siswa pada konsep asam basa. Jurnal Penelitian dan Pembelajaran IPA, 1(1), 16. doi: https://doi.org/10.30 870/ jppi.v1i1.324

Everaert, P., Opdecam, E., \& Maussen, S. (2017). The relationship between motivation, learning approaches, academic performance and time spent. Accounting Education, 26(1), 78-107. doi: https://doi.org/10. 1080/09639284.2016.1274911

Firmansyah, F., Komala, R., \& Rusdi, R. (2018). Self-efficacy and motivation: Improving biology learning outcomes of senior high school students. JPBI (Jumal Pendidikan Biologi Indonesia), 4(3), 203-208. doi: https://doi.org/10.22219/jpbi.v4i3.6878

Ghazivakili, Z., Norouzi Nia, R., Panahi, F., Karimi, M., Gholsorkhi, H., \& Ahmadi, Z. (2014). The role of critical thinking skills and learning styles of university students in their academic performance. Journal of Advances in Medical Education \& Professionalism, 2(3), 95-102. Retrivied from https://www.ncbi.nlm. nih.gov/pmc/articles/PMC4235550/

Glaze, A. L. (2018). Teaching and learning science in the 21 st century: Challenging critical assumptions in postsecondary science. Education Sciences, 8(1), 1-8. doi: https://doi.org/10.3390/educsci8010012

Häkkinen, P., Järvelä, S., Mäkitalo-Siegl, K., Ahonen, A., Näykki, P., \& Valtonen, T. (2017). Preparing teacherstudents for twenty-first-century learning practices (PREP 21): a framework for enhancing collaborative problem-solving and strategic learning skills. Journal Teachers and Teaching Theory and Practice, 23(1), 25-41. doi: https://doi.org/10.1080/13540602.2016.1203772

Handayani, L. G., Subagia, I. W., \& Pujiani, N. M. (2015). Kontribusi factor-faktor yang mempengaruhi literasi sains siswa SMP Negeri Se-Kabupaten Buleleng. Jurnal Penelitian Pascasarjana Undiksa, 5(1), 1679. Retrieved from https://oldpasca.undiksha.ac.id/e-journal/index.php/jurnal_ipa/article/view/1679

Handayani, G., Adisyahputra, A., \& Indrayanti, R. (2018). Correlation between integrated science process skills, and ability to read comprehension to scientific literacy in biology teachers students. Biosfer, 11(1), 2232. doi: https://doi.org/10.21009/biosferjpb.11-1.3

Hasenbank, J. F. (2006). The effects of a framework for procedural understanding on college algebra student's procedural skill and understanding. Montana State University, Bozeman. Retrived from https://search.proquest.com/openview/7e1bfe6d6ab0a9701161 cb507f1ef37a/1?pq-origsite=gscholar\&c $\mathrm{bl}=18750 \&$ diss $=\mathrm{y}$

Holbrook, J., \& Rannikmae, M. (2009). The meaning of scientific literacy. International Journal of Environmental \& Science Education, 4(3), 275-288. Retrieved from https://files. eric.ed.gov/fulltext/EJ8 84397.pdf

Husamah, \& Pantiwati, Y. (2014). Cooperative learning STAD-PjBL: motivation, thinking skills, and learning outcomes of biology department students. International Journal of Education Learning and Development, 2(1), 77-94. Retrieved from https://www.eajournals.org/journals/international-journal-of-educationlearning-and-development-ijeld/vol-2-issue-1-march-2014/cooperative-learning-stad-pjbl-moti vationthinking-skills-learning-outcomes-biology-department-students/ 
Jariyah, I. A. (2017). The effect of inquiry combined science-technology-society (STS) learning to enhance critical thinking skills on science. JPBI (Jurnal Pendidikan Biologi Indonesia), 3(1), 1-9. doi: https://doi. org/10.22219/jpbi.v3i1.3888

Johari, A., Tom, A. A., Morni, A., \& Sahari, S. H. (2013). Students' reading practices and environments. Indonesian Journal of Applied Linguistics, 3(1), 17. doi: https://doi.org/10.17509/ijal.v3i1.187

Karademir, E., \& Ulucinar, U. (2016). Examining the relationship between middle school students' critical reading skills, science literacy skills and attitudes: A structural equation modeling. Journal of Education in Science, Environment and Health, 3(1), 29-29. doi: https://doi.org/10.21891/jeseh.275669

Karakoç M. (2016). The significance of critical thinking ability in terms of education. International Journal of Humanities and Social Science, 6(7), 81-84. Retrieved from doi: http://www.ijhssnet.com/journals/Vol_6 No_7_July_2016/10.pdf

Lishinski, A., Yadav, A., Good, J., \& Enbody, R. (2016). Learning to program: Gender differences and interactive effects of students' motivation, goals, and self-efficacy on performance. In Proceedings of the 2016 ACM Conference on International Computing Education Research (pp. 211-220). New York, NY, USA: ACM. doi: https://doi.org/10.1145/2960310.2960329

Lukitasari, M., Hasan, R., \& Murtafiah, W. (2019). Using critical analysis to develop metacognitive ability and critical thinking skills in biology. JPBI (Jurnal Pendidikan Biologi Indonesia), 5(1), 151-158. doi: https:/l doi.org/10.22219/jpbi.v5i1.7262

Muhammad, S. N., Listiani, L., \& Adhani, A. (2018). Hubungan antara literasi sains dan rasa ingin tahu siswa pada materi ekosistem. Natural: Jurnal IImiah Pendidikan IPA, 5(2), 112. doi: https://doi.org/10.30738/ natural.v5i2.2935

Mulnix, J. W. (2012). Thinking critically about critical thinking. Educational Philosophy and Theory. doi: https://doi.org/10.1111/j.1469-5812.2010.00673.x

Nurul, Azizah, A., Suryanda, A., \& W, R. D. (2018). Hubungan kebiasaan membaca dengan kemampuan literasi sains siswa SMA di Jakarta Timur. Bioma: Jurnal IImiah Biologi, 7(2), 161. doi: https://doi.org/ 10.26877/bioma.v7i2.2804

OECD. (2010). PISA 2009 Results: What students know and can do: Student Performance in reading, mathematics and science (Volume 1). Source OECD Education and Skills. doi: https://doi.org/10.1787/ 9789264091450-en

OECD. (2019). PISA 2018 results. OECD Publishing. Retrieved from https://www.oecd.org/pisa/publications/ pisa-2018-results.htm

Purwani, L. D., Sudargo, F., \& Surakusumah, W. (2018). Analysis of student's scientific literacy skills through socioscientific issue's test on biodiversity topics. Journal of Physics: Conference Series, 1013(1), 12-19. doi: https://doi.org/10.1088/1742-6596/1013/1/012019

Radulović, L., \& Stančić, M. (2017). What is needed to develop critical thinking in schools? CEPS Journal : Center for Educational Policy Studies Journal, 7(3), 9-26. Retrieved from https://files.eric.ed.gov/fulltext IEJ1156618.pdf

Rahayu, A. H. (2014). Analisis penyajian panduan pembelajaran literasi sains dalam buku tematik terpadu kelas IV kurikulum 2013. Mimbar Sekolah Dasar, 1(2), 226-233. doi: https://doi.org/10.17509/mimbarsd.v1i2.887

Rahayuni, G. (2016). Hubungan keterampilan berpikir kritis dan literasi sains pada pembelajaran IPA terpadu dengan model PBM dan STM. Jurnal Penelitian dan Pembelajaran IPA, 2(2), 131-140. doi: https://doi. org/10.30870/jppi.v2i2.926

Saptasari, M., Sunarmi, S., Sulasmi, E. S., Wicaksono, R. S., \& Sudrajat, A. K. (2019). Information literacy skill: An alternative to support biology student's learning outcomes. JPBI (Jurnal Pendidikan Biologi Indonesia), 5(3), 451-458. doi: https://doi.org/10.22219/jpbi.v5i3.8768

Singh, B., Kaur, A., \& Brar, K. S. (2017). Information literacy and learning styles: An overview of resource-based studentcentred learning. Journal of Management Research and Analysis, 4(3), 84-86. doi: https://doi.org/10.18231/2394-2770.2017.0012

Stephen . Robbins, \& Judge, T. A. (2012). Organizational behavior. New Jersey: Pearson Education. Retrieved from https://lib.hpu.edu.vn/handle/123456789/32479

Susiani, T. S., Salimi, M., \& Hidayah, R. (2018). Research based learning (RBL): How to improve critical thinking skills? In SHS Web of Conferences (Vol. 42, pp. 2-6). doi: https://doi.org/10.1051/ shsconf/ 20184200042

Susiati, A., Adisyahputra, A., \& Miarsyah, M. (2018). Correlation of comprehension reading skill and higherorder thinking skill with scientific literacy skill of senior high school biology teacher. Biosfer, 11(1), 1-12. 
doi: https://doi.org/10.21009/biosferjpb.11-1.1

Suwono, H., Pratiwi, H. E., Susanto, H., \& Susilo, H. (2017). Enhancement of students' biological literacy and critical thinking of biology through socio-biological case-based learning. Jurnal Pendidikan IPA Indonesia, 6(2), 213. doi: https://doi.org/10.15294/jpii.v6i2.9622

Suwono, Hadi, Mahmudah, A., \& Maulidiah, L. (2017). Scientific literacy of a third year biology student teachers: exploration study. KnE Social Sciences, 1(3), 269. doi: https://doi.org/10.18502/kss.v1i3.747

Toharudin, U., Hendrawati, S., \& Rustaman, A. (2011). Membangun literasi sains peserta didik. Bandung: Humaniora. Retrieved from https://opac.perpusnas.go.id/DetailOpac.aspx?id=630282\#

Ulger, K. (2018). The effect of problem-based learning on the creative thinking and critical thinking disposition of students in visual arts education. Interdisciplinary Journal of Problem-Based Learning, 12(1), 1-21. doi: https://doi.org/10.7771/1541-5015.1649

Wahyuni, S., Miarsyah, M., \& Adisyahputra, A. (2018). Correlation between achievement motivation and reading comprehension ability through science literacy to high school students. Indonesian Journal of Science and Education, 2(2), 115-124. doi: https://doi.org/10.31002/ijose.v2i2.613

Yuriza, P. E., Adisyahputra, A., \& Sigit, D. V. (2018). Correlation between higher-order thinking skills and level of intelligence with scientific literacy on junior high school students. Biosfer, 11(1), 13-21. doi: https:// doi.org/10.21009/biosferjpb.11-1.2

Zascavage, V. (2010). Critical thinking skill and the intervention specialist. Journal of Border Educational Research., 8(1), 71-80. Retrieved from https://pdfs.semanticscholar.org/1b07/ab96ee04c675075822f 79ffde0e2a196cbce.pdf?_ga=2.29715450.490005324.1599471017-1801622107.1584710897 